GEVER VERLUMUN CELESTINE,

\title{
EFFECT OF MOBILE PHONE COMMUNICATION MESSAGES ON PARTICIPATION IN AGRICULTURE AMONG UNIVERSITY UNEMPLOYED GRADUATES
}

The article analyzes an influence of $\mathbf{4 1 2}$ SMS from Mtn Nigeria agro info Services Added Value that were sent by graduates of universities with agricultural specialties during 2018. The author examined the content of those messages and their effectiveness in decision making by young specialists about their employment in Nigerian agricultural enterprises. For this purpose the author divided all messages into four categories ("evidentiary", "local", "descriptive", "striking"). Of them, "evidentiary" messages were the most effective in communication by encouraging unemployed to make constructive decisions about their employment. Generally, the results of the research demonstrates that the messages sent to mobile phones are effective means in attraction of the qualified specialists to the work in agriculture sector of the county. Apart from historical, sociological component of this research is also important, because unemployment of graduates of universities makes them vulnerable and may influence negatively on the society. It is also important that the research may result in positive changes in certain behavior patterns, because now mobile phone is an effective means of not only communication, but also forming of certain tastes and values. Finally, the results of this research may influence on substantive content for mobile phone users, because they reflect a rather significant multiaspectual effectiveness of the named categories of SMS. Therefore, the most important innovation of the article is an evidence of the influence of mobile communication on important behavior reflexes; given facts and conclusions may be useful and instructive for telecommunication service providers and communications experts, as well as for managers of agricultural enterprises, social workers and researchers on this issue. The most important result of this research is the demonstration that due to the receiving agro-informational hints by unemployed graduates of universities a large part of them found employment, at the same time, those who did not regard this information remained unemployed.

Keywords: agriculture; communication; messages; university graduates; participation.

\section{Introduction}

One of the problems facing world today is how to cater for its teeming youth unemployment. The situation is such that even the educated youths are not spared as graduate unemployment has continued to increase. Figures from the International Labour Organization (2016) suggests that the world is facing its most trying moment with regard to the future of educated youths. According to the Labour Organization, "the number of unemployed youth globally will rise by half a million in 2016 to reach 71 million and will remain at this level in 2017. (p.VII)." The situation in Nigeria is particularly worrying as youth, even after acquiring western education, remain either completely unemployed or underemployed. This is evidenced in the increasing number of graduate unemployment in Nigeria. Available statistics from the National Bureau of Statistics (2016) for the second quarter of 2016, showed that the total number of youth unemployment/underemployment was $49.5 \%$. Ezeah and Gever (2017) argues that the situation may even be worse considering that every four months, each of the 36 states of the Federation, as well as the Federal Capital Territory, Abuja produce an average of 2000 youths into the labour market after completion of compulsory one year mandatory service. Ezeah and Gever further recalled the incidence of 2013 when the Dangote Group of Companies needed 100 drivers to fill existing vacancies. Out of the 13,000 applications received, there were 6 Ph.D. holders, 704 Masters and over 8,460 first degree holders. Considering the limited employment opportunities in Nigeria, agriculture is considered as a viable option through which unemployed graduates can gainfully engage themselves and create wealth. However, the problem is that most graduates are not interested in agriculture. They feel that agriculture is meant for the uneducated. This assumption is supported by evidence in literature as Ibitoye (2011) studied 600 youths in Nigeria and reported that they have negative attitudes towards agriculture. Beyuo and Bagson (2011) reported similar result after studying youths from Ghana. Also, Maina and Maina (2015) revealed the same result after studying youths from Kenya.

Considering the seeming wide acceptance of the mobile phone among university graduates, who are mostly youths, it has the potential of serving as a tool to persuade university graduates to take part in agriculture. The mobile phone can serve as a platform to educate graduates on the need to take part in agriculture. Ekwueme and Gever (2017) argue that the mobile offers an express avenue 
through which people can be persuaded to participate in agriculture. The researchers note: "in this era of growing acceptance of the Global System for Mobile Communication (GSM), its application for the purpose of promoting agricultural activities will go a long way in enhancing food production" (Ekwueme and Gever, 2017: 55).

Mobile phones, just like the Internet, have significantly modified the way things are done in contemporary society. In the present day society, spheres of the society like the economy, security, governance, religion, communication, among others have substantially depended on mobile telephone to function. Scholars (e.g., Aricat, Karnowski \& Achib, 2015; Sahota \& Kameswari, 2014; Chatterjee, 2014, Khayyat \& Heshmati, 2013) agree that mobile telephone has become pervasive, infiltrating almost all aspects of the society and its services have changed people's lifestyles by transforming and revolutionizing the way they work and interact. In addition, they have provided opportunities for a powerful communication medium to influence business and social life. Chatterjee captures the centrality of mobile phones thus: "Mobile phones have become the most important and integral part of today's life style and mobile handset has become a widely recognized consumer artifact" (p.55). The submission of Chatterjee, does not only offer insights on the pervasiveness of mobile phone, but also shows the potentials inherent in this new communication technology as a tool for agricultural development.

Mobile phone has been considered as playing a central role in information gathering processing and dissemination about agriculture thereby promoting agricultural activities. Razaque and Hassan (2013) aver that farming communities appreciate mobile phone as easy, fast and convenient way to communicate and get prompt answers of respective problems and that nowadays, the mobile phone has generated an opportunity for the farmers to get the information about marketing and weather. The authors add that through this technology, farmers directly keep in touch with market personnel and offer their produce with reasonable prices. Haruna, Jamilu, Abdullahi and Murtala, (2013: 14) corroborate thus:

Mobile phone provides existing new ways through which extension workers can reach farmers in rural areas that have in the past been very difficult to contact, particularly in developing countries like Nigeria. Ownership and use of mobile phone among the rural farmers has continued to increase thereby increasing the chances of contacting farmers in their communities for extension activities.

Anjum, et al (2015) share similar view on the pivotal role that mobile phone plays in agricultural communication. Farmers at all level seem to have also realized the potentials of of the mobile phone as the device is very common to them. They carry it along even when going to the farm. This, no doubt has made agricultural communication easier.

\section{Theoretical Framework}

Although there may be other frameworks to anchor this study, the ACADA model was thought to be most appropriate considering that it fully incorporate communicate into the process of behavior change campaign. The model is an acronym for Assessment, Communication, Analysis Design and Action. It was developed by the United Nations for International Children Emergency in 2001. This model is informed by the fact that influencing or modifying human behavior through communication is a complex process that needs to be planned carefully (Ekwueme \& Gever, 2017). The stages of the model are as follows:

Assessment Stage. This is the first stage of the ACADA

ISSN 1728-9343 (Print)

ISSN 2411-3093 (Online) model wherein the main objective is researching into the real situation as well as knowing its nature, characteristics, history and current status, those involved and the social cultural environment. In this instance, this stage will be aimed at understanding the level of graduate involvements in agriculture, the hunger threats, unemployment situation, among others.

Communication Analysis. During this stage, the essence is to carry out series of activities like, analysis and formulation of the problem, determination of problem to address, behavior analysis, participant analysis, channel analysis/ media analysis, statement of communication objectives, identification of communication strategy and activities, development of monitory and evaluation indicators. The crux of the matter here is how best communication can solve the problem so identified.

Design stage. At this stage, the aim is to package a design that suite the target group. The message is designed through the instrument of persuasion, enlightenment and full information. The communication materials and messages are to be pretested and modified in line with the programme objectives (Okorie, 2013). The choice of the mobile phone for this study is an attempt to use a medium that is most known to the target.

Action. This is the last stage in the model. It is the point where what is planned is implemented. For this study, it is a point where the messages are sent to university graduates through their mobile phones.

Use of Mobile Phone Technology among University Graduates

University graduates are people who have completed a course of study at the university. In most cases, they are largely youths within the ages of 20-29 years. In Nigeria, to qualify for admission into the university, a person must not be less than 16 years of age and to participate in the compulsory National Youth Service, a person must not be more than 30 years. The very fact that most people who graduate in Nigerian universities and even abroad take part in the mandatory service year suggest that they are usually less than 30 years. Even while still in the university, undergraduates make use of the mobile phone to meet their communication needs. Walsh et al. (2008) and Ogunyemi, (2010) note that the mobile phone is used by university students in the United Kingdom (UK) and Australia for many other functions, such as alarm clock, camera, music player, diary and phonebook. Chen and Katz (2009) found that university students in the United States of America (USA) said that owning a mobile phone is important for keeping in contact with their parents, to ask for advice or get emotional support. Even when students graduate from the university, they continue using their mobile phones.

After graduation from the university, most graduates make use of the mobile phone to communicate with classmates, friends and even family members Some graduates use their mobile phones for job alerts, other for social networking. Some also use it to surf the Internet for existing job opportunities. Other even use it to get samples on how to write their curriculum vitae. The important point to notes here is that the mobile phone is a very essential device through which through which university graduates meet their information, integration and socialization needs. This tool can serve as a means through which behavior change information can be communicated to these graduates.

Mobile Phone as a tool for behavior Change Communication

Behavior change communication is aimed at promoting positive behavior among the target receivers. The hall

SKHID No. 2 (160) March-April 2019 
mark of behavior change communication is to ensure that people accept and practice acts that are beneficial to them and the society as a whole. In behavior change communication, the essence is to ensure that people graduate from the point of being unaware to the point of awareness, to knowledge, to motivation to change, to practicing trial behavior and ultimately sustain such behavior (Gever \& Nwabuzor, 2014). Behavior change communication is part of strategic communication. Paul (2011: 3) defines strategic communication as "co-ordinated actions, messages and other forms of signaling or engagement intended to inform, influence or persuade selected audience to support national objectives." The import of the definition of Paul is that it places emphasis on informing and persuading selected audience The United Nations Children's Fund (2005: 6) provides further insights into strategic communication thus:

Strategic communication is an evidence-based, result-oriented process undertaken in consultation with the participant group intrinsically linked to other programme elements, cognizant of the local context and favouring a multiplicity of communication approaches to stimulate positive measurable behavior and social change.

The submission above has further shown the essence of behavior change communication. One of the factors to consider in behavior change communication is the choice of media. That is, the channel through which the information reaches the target is very important. Marshall McLuhan corroborates that the medium is the message. The first thing to be said about the medium is the message is that it is a warning and a wake-up call. It is a plea to pay attention, for as McLuhan insists in The Medium is the Massage, "there is absolutely no inevitability as long as there is a willingness to contemplate what is happening" (McLuhan \& Fiore, 1967: 25). The medium, is, therefore, very important in behavior change communication.

Considering the wide acceptance of the mobile phone as a means of communication, it has the potential of serving as a vehicle for behavior change communication. The mobile phone have the potential of serving as a medium through which behavior change communication messages can be sent to target receivers. People can forget to turn on their radio set, TV, or buy a copy of newspaper or magazine, but their mobile phone is always handy. At places of work, motor parks, places of worship, market, eateries, on transit, in school, at lecture venues, on bed, on the dining table, the mobile phone is handle, it is simply a phenomenon and a technological miracle of the $21^{\text {st }}$ century. Both the educated and the uneducated alike have found the mobile useful. The use of the phone also cuts across occupation as public and civil servants, security agencies, business men and women, farmers, artisans, herdsmen, among others are engaged in the use of mobile phone for one thing or the other.

Evidence in literature also suggests that the mobile phone can serve as a viable option for behavior change communication. Boaz, et al (2016) investigate the access and use of mobile phones for improving the coverage of agricultural extension services among farmers in the preharvest stages of maize value chain in Kilosa district in Tanzania and found that that majority of respondents used mobile phones and had a positive attitude on the contribution of mobile phone in their farming business. The study results also indicated that mobile phones offered an affordable solution to farmers' information needs and information requirements. Egbule, et al (2013) did a study in Nigeria and reported a similar result.

The mobile phone has also been used to change behavior in the education subsector. Valk et al (2010) examined the evidence of the role of mobile phone-facilitated mLearning in contributing to improved educational outcomes in the developing countries of Asia by exploring the results of six mLearning pilot projects that took place in the Philippines, Mongolia, Thailand, India, and Bangladesh. The result showed that the mobile was successful in increase access to education. Scholars (e.g. Haapala, et al, 2009; Franklin, et al, 2006; Fjeldsoe, et al, 2009; Whittaker, et al, 2009; Cole-Lewis, Kershaw, 2010) have also examined the effectiveness of the mobile phone in health behavior modification and the outcome showed that the mobile is an effective tool for health communication. However, there still exist paucity of literature examining the effect of mobile phone messages in promoting participation in agriculture among university graduates, especially in developing countries like Nigeria.

The Message as a tool for Behavior change communication

The message is a very essential component of the communication process. Apart from the medium, the content plays a critical role in deciding the reactions of the receivers. Wigington (2008) opines that considering the centrality of the message in communication, its development should be taken seriously. The National Archives (2013) notes that message should conform with the following: keep it short and simple. The message must be clear, concise and complete.

Okoro (2017) avers that for communication to be effective, its message must be candid, clear, complete, concise, concrete, correct and courteous. The central idea is that the message is at the heart, soul and body of knowledge transfer. The message can be classified into different categories. Li-Shia et al (2007) in a study found that the message types significantly influence the behavior. Their result revealed that instrumental messages are more influential than affective messages. The result of Li-Shia et al. also showed that a significant interaction effect exists between message types and reading motives. Also, Nguyen and Fussell (2013), Li, (2006) and Otondo, et al (2008) have also reported that the message contents greatly influence the receivers of such messages. Ekwueme and Gever (2017) in a study reported that the message content for promoting agriculture should be properly crafted such that it educates and at the same time persuade people to get involved in agriculture. The researchers found that agriculture has image problem, especially among the educated youth who are ill-disposed to it.

It is important to add here that telecommunication services providers in Nigeria have also realized the potentials of the mobile phone in changing behavior. Consequently, they have initiated different Value Added Services (VAS) through which they send messages to subscribers on different issues like health, security, agriculture, education, etc. Subscribers only receive such messages if they subscribe to such services and a certain amount will be deducted from their accounts on regular basis. A good example of such services is the $m t n$ Nigeria agro info tips which provides regular tips to subscribers on a regular basis while N50 is deducted from their account after 7 days. Mostly, the telecommunication services providers get subscribers by sending them invitation messages. Mtn Nigeria is one of the leading telecommunication services providers in Nigeria. According to the Nigeria Communications Commission (2017), Mtn Nigeria has the largest market share of $36.07 \%$. The motivation for this study began when one of the researchers received an invitation message in January, 2016 to subscribe to agro info tips services service. The message read: "Nigeria targets 2016 for self-sufficiency in food production via 
farming. It begins in food production via farming. It begins with you, get more information on business of farming. Text AGRIC to 2707." Although the agro info has been ongoing with a view to promoting participation in agriculture, studies have not be sufficiently carried out to measure its effectiveness. There is also paucity of literature that provide insights into the messages sent out by such services.

The objectives of this study therefore are:

1. To examine the message contents of Mtn Nigeria agro info Value Added Service.

2. To determine the effectiveness of such messages on participation in agriculture among university graduates in Nigeria.

3 . To ascertain the specific aspect of such messages that have effects on university graduates.

\section{Study 1: Content analysis of Mtn agro info messages} Methods

In the first study, the intention of the researchers was to generate short messages from Mtn agro info Value Added Services and analyse them. To achieve this, AGRIC was sent to 2707 through a mobile number 08064938817 on January $3^{\text {rd }}, 2016$. We then opened a log book where all the short messages sent were documented. This lasted for a period of 412 days. That is one year 46 days. When these messages were received, we then developed four coding categories as follows:

Evidential: Messages were classified as evidential if they provide evidence in figures or practical terms on the benefits of agriculture.

Locatial: We considered messages as locatial if they provide location concerning where agricultural activities can best be carried out, or where to locate improved seedlings or where to sell agricultural products

Descriptial: Messages were considered as descriptial if they merely describe the importance of participating in agriculture.

Impactial: Messages were considered as impactial if they attempt to educate people no how to carry out agricultural activities.

Two coders were then engaged and given the code guide as well as the written out messages. They were asked to code the messages based on frequency of occurrences of the categories (evidential, Locatial, descriptial, and impactial). In the process of coding, it was discovered that the coders disagreed on the categories of some of the short messages. We highlighted such areas and later discussed them until $95 \%$ agreement was reached. The short messages were also subjected to a inter-coder reliability test. Riffe et al (2005) make a case for a random selection of content samples for inter-coder reliability testing. In the same direction, Wimmer and Dominick (2013) recommended that between 10- 25\% of the body of content should be tested. Therefore, we determined the inter-coder reliability for this study using a randomly selecting $10 \%$ of the short messages. Using Holsti's formula (cited in Wimmer \& Dominick, 2006), the inter-coder result revealed the inter-coder reliability of 0.72 . In the analysis of the results, simple percentages were used while the results were presented in a chart.

\section{Results}

The result of the first study was aimed at providing insights into the nature of short messages provided by the Mtn agro info Value Added Services. After coding the messages along four delineated categories, the result is presented in the following chart.

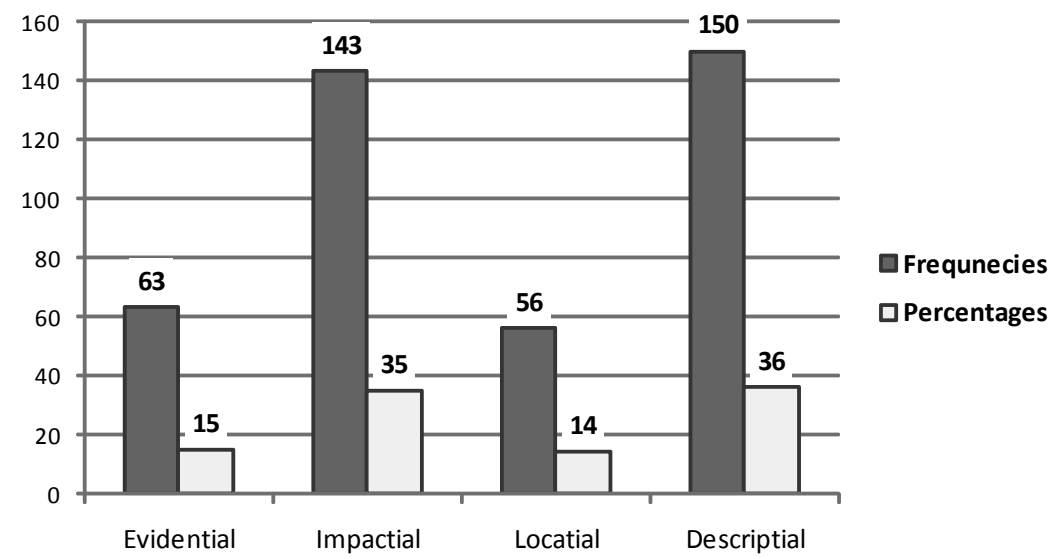

Fig 1: Categories of messages sent by Mtn Nigeria on agricultural tips.

The result from the chart above revealed the dominance of descriptial and impactial in the message categories that the Mtn Nigeria sent out to its subscribers to agric info tips from January 2016 to February, 2017. The dominance of these two categories point out two things. First, it showed that most of the messages were aimed at educating subscribers on agricultural techniques and describing its benefits to them. Second, it showed that such could educate the subscribers and describe agricultural products to them without convincing them to participate. Conversely, they may be convince to join after being educated. Although we understood categories of messages that Mtn Nigeria sent to subscribers through its agro info Value Added Service, we did not understand if such messages actually have effects on the subscribers. To achieve this, a second study was necessary.

ISSN 1728-9343 (Print)

ISSN 2411-3093 (Online)
Study II. Effectiveness of messages on participation in agriculture among university graduates in Nigeria Methods

After getting the agro info tips of Mtn Nigeria from study 1 , the second study sought to measure the effectiveness of such messages. We recruited a total of 32 (16 males and 16 females) university graduates for the second phase of the study. The mean age of the respondents was 26 years (range 23-28 years). The mean number of years of graduation from the university was 5 (range 2-8). The selected graduates were not working at all as at the time of participation in this study. They also reported not havening any intention of venturing into agriculture as because they were applying for jobs. They also had mobile phones and were using it daily. The mean number of years of usage of mobile phone was 9 years (range range 8-10).

SKHID No. 2 (160) March-April 2019 
With regard to the course of study in school 5 studied Mathematics, 6 studied Biological sciences, 2 studied Mass Communication, 7 Studied Political Sciences, 2 studied Pharmacy, 1 Studied English and Literary Studies, 3 Studied Economics and 6 Studied Chemistry.

We selected the respondents for this study through purposive sampling. It was decided that purposive sampling was best for this study because it best helped in reaching the desired respondents. We used an experimental approach for this study. This experiment was based on the following hypothesis:

H1: University graduates who are exposed to Mtn agro info tips are likely to participate in agriculture than those not exposed.

\section{The Experimental Process}

We collected all the mobile numbers of the study participants. Their names and phone numbers were written in alphabetical order and from 1-32. We then gathered them at the Examination hall, of Community Secondary School, Ede-Oballa where they were briefed about the essence of the study. Consequently, we asked them to sign a consent form. We told them that we were going to be contacting them via their mobile phone numbers. After that, we then decided that the first 16 were the treatment group and the other 16 the control group. We gave them a number through which we were reaching them and discouraged them from sharing the contents of either call or text from the research team among themselves.

We targeted twelve calendar months so the study opened on February 22, 2016 and ended on February, 21, 2017. It is important to add here that even though we started collecting the short messages from Mtn Nigeria in January, 2016 the treatment began in February, 2016. It should also be noted that during the period of the treatment, we were also calling the control group on interval of one week to find out their welfare and assure them that the study was still ongoing and get commitment from them if they were still part of the study. We allowed the respondents the period of February to September, 2017 so as to better determine the effect of the treatment. On October $5^{\text {th }}$, we then called all the participants and gave them a questionnaire to provide information on their job status. They were told to indicate their serial numbers as contained in the study book on their questionnaire for easy separation of the control from the treated group.

\section{Semi-Structured interview}

After the experiment, a semi-structured face-to-face interview was scheduled with the respondents. The interview was conducted in three days and each interview lasted between 30 to one hour. The essence of the interview was to understand the aspect of the text messages that interested and influenced them. We were also interested in understanding their views about the short messages sent to them. We only interview members of the control group who reported in the questionnaire that they were involved in agriculture.

\section{Data Analysis}

We combined both qualitative and quantitative method of data analysis for the study. We used the t-test to determine the mean difference between the treatment and the control group. It should be noted that we attached codes to the quantitative response for ease of analysis. Therefore, those who said that they were involved in agriculture activities were scored 3 while those who said they were not were scored 1 . We used thematic analysis to analyse the semi-structured interview which took place after filling of the questionnaire. We transcribed all the interviews verbatim and read them many times for better understanding. We also checked all the transcribed interviews for accuracy. After which we followed Brawn and Clark (2006: 79) 'patterns' within the data in our analysis. We also followed the guide to the phases of conducting the thematic analysis. These are: familiarity with the data, gathering initial code, searching for themes (vital concepts, explanatory ideas, recurring ideas etc.); reviewing the themes, defining and naming the themes and producing the report inform of illustrative quotes.

\section{Results}

An independent-sample t-test was conducted to compare the participation in agriculture scores of university graduates who were exposed to agro info tips through their mobile phones and those not exposed. The result showed a significant difference between the treatment group $(\mathrm{M}=2.3750, \mathrm{SD}=.95743)$ and control group $(\mathrm{M}=$ 1.5000, $\mathrm{SD}=.89443 ; \mathrm{t}(30)=2.671, \mathrm{P}=1.2$, two tailed). The magnitude of the differences was 87500 . Based on the result of this study, the lone hypothesis of this study is proven and we conclude that there is $95 \%$ chance that university graduates who are exposed to short messages on agricultural tips are likely to participate than those not exposed.

\section{Interview Results}

We held semi-structured interviews of the respondents for two broad reasons. First, to understand the aspects of the text messages that interested and influenced them. We were also interested in understanding their views about the short messages sent to them. For the control group, our interest was to understand why they were not engaged in agriculture. The result of the study showed that most of the treatment group participants were very excited about the text messages on agricultural tips sent to their mobile phones. They also reported that such text messages served as a spring board for them to participate in agriculture. One of the respondents said:

Such text were very inspiring. At a point, I had no option but start thinking of agriculture. Right now, my fish pond is growing and my customer base is also expanding. I am more focused now than when I was looking of nonexisting jobs. I am happy that I took part in this study. My next plan is to set up a poultry farm.

Our result also showed that some participants had also invested in crop production as a result of exposure to message through their mobile phones. One of the respondents said: "The messages kept coming and at a point, I just needed to start something. Today, if you see my cassava farm, you will be shocked." Another participants said: "I am currently into agriculture full time. As soon as I am done with this interview, off, I go". Some of the respondents even expressed regrets for not engaging in agriculture earlier, therefore wasting precious time. "I wish, I started earlier". "Had I know, by now, I would have been a big man. Just look at me, after 6 years of graduation, I am just defining purpose in life." "The good thing is that I will no long beg for money nor job". There were also those who were into buying and selling of agric products. "What I now do is to buy during harvest and resell when demand is higher". Said another participants. We probed the respondents to ascertain which message type influenced them more and their responses indicate that the evidential messages were most effective followed by locatial. One of the respondents said: "when a message has verifiable evidence, it makes the argument stronger". Another one said: "Some of the messages contained evidence that had compelling influence". Another one said: "Even in court, evidence is sacrosanct, messages with facts and figures greatly had effect on me". When we asked them to supply some of the messages they could recalled, we got the following: 
Demand for fish is currently put at millions of tons in Nigeria, $40 \%$ are locally sourced while $60 \%$ are imported. This shortfall potent a huge opportunity.

Investment in small scale cassava processing business is good especially cassava chips and starch production. The export value is high and are very profitable.

Stand a chance to benefit from coconut as Lagos State ministry of Agric revealed plans to expand structure for its production and processing. Don't be left out!

Double your income with quick returns through meat production. If you grow broilers, within 42-45 days most broilers are grown and reads to be sold to consumers.

Irrespective of your job, you can augment your earning in December by investing in small scale rearing of broilers chickens, their maturity is 12 weeks.

In summation, therefore, out of 16 treated members, 11 representing $69 \%$ had started participating in agriculture. Among the reaming 5 representing $31 \%$ percent, we sought to know if they had intention of participating in agriculture and 4 representing $25 \%$ said they were already in the process of starting while the remaining 1 representing $6 \%$ said she was not thinking of engaging in agriculture in the near future. When we asked her why, she retorted: "I simply do not like agriculture". We also noticed that the lone participant who refused to participate in agriculture had graduated two years ago. This could be the reason she was still adamant or could also be her gender. We also noticed that among the control group, 4 persons representing $25 \%$ had started participating in agriculture. We probed them further to gain insights into the sudden change and discovered that they had contacts with some members of the treatment group. Therefore, when they saw them participating in agriculture, they also had to join. Based on this, we concluded that peer influence was responsible for their involvement in agriculture. The influence was a spillover of the treatment.

\section{Discussion of Findings}

The result of this study showed that short message sent through the mobile phones of users are very effective in behavior change communication. The result has shown that when unemployed university graduates are exposed to agricultural tips, there is $95 \%$ chance that it will likely have affect on their participation in terms of involvement in crop production, rearing of animals as well as marketing of agricultural products. This result is consistent with previous studies (e.g. Haapala, et al, 2009; Franklin, et al, 2006; Fjeldsoe, et al, 2009; Whittaker, et al, 2009; ColeLewis, Kershaw, 2010; Egbule, et al, 2013; Boaz, et al, 2016). The result of this study differs from previous studies because it made use of short messages from the telecommunication service providers and not just drafting imagined messages. This study also differs from others because it did not focus on existing farmers, but fresh university graduates who were not interested in agriculture at all. This is a complete departure from other studies (e.g., Anjum, 2015; Boaz, et al, 2016) that examined the role of mobile phone in agriculture. This new dimension could be useful because farming requires energy and the youth who still have the energy are hardly interested in venturing into farming. The situation is even worst with the educated ones, a situation that has led to increased ruralurban migration. This study has implications on ACADA model because it has shown that when a problem is identified, properly analysed and the appropriate communication approaches are applied, it is likely to yield the desired result. The result has also shown that ACADA model could be an appropriate framework for studying behavior communication through the mobile phone.

ISSN 1728-9343 (Print)

ISSN 2411-3093 (Online)
Consequently, this result provides the theoretical support for subsequent researchers who may be interested in understanding how the mobile can be used as a channel of communication aimed at changing behavior.

\section{Conclusion}

This study set to achieve trio objectives of: examining the message contents of Mtn Nigeria agro info Value Added Service; determining the effectiveness of such messages on participation in agriculture among university graduates in Nigeria and ascertaining the specific aspect of such messages that have effects on university graduates. These objectives were achieved through two different but complementary studies. The first study examined the message type sent to subscribers through Mtn agro info Value Added Services. The message were coded along four categories namely evidential, locatial, descriptial and impactial. Our result showed that most of the messages were descriptial and impactial. In the second part of the study, we found that evidential messages were most effective in attitude change communication. The implication of this result is that messages aimed at promoting participation in agriculture should contain more evidential elements than descriptial, impactial and locatial. Overall, our result suggests that messages sent through the mobile phone of subscribers are very effective in promoting participation in agriculture among those who are not interested in participating in agriculture.

This result has three broad implications. First, the result of this study has sociological implications because unemployment and food security are sociological issues. When university graduates are unemployed, they are vulnerable to crime and other social vices and this may have a negative influence on the society. When there is hunger, it is equally a sociological problem because this makes people vulnerable to different vices. Therefore, by providing evidence based-understanding on how the mobile phone could be effective in persuading youth to participate in agriculture, this study has addressed a sociological issue. Second, this study has implication on behavior change communication because it has shown that the mobile phone could be an effective medium of communicating attitude change messages to the target receivers. In the third place, the result of this study has implications on ACADA model because it has shown that the model could be useful as a framework for examining mobile phone and behavior change communication. Finally, this result has implications on the crafting of messages for mobile phone users as it has shown that not all messages are effective in behavior change. This means, the crafting of short messages must be carefully done so as to achieve the desired results. Therefore, the basic contribution of this study is that it has provided evidence for understanding the effect of mobile phone communication on behavior change campaigns. The study has also addressed sociological problems of unemployment and hunger. We hoped that the result of this study will, therefore, be useful to telecommunication services providers, agricultural extension worker, social workers, communication experts as well as researchers. We recommend, therefore that further studies should be expanded to include other critical aspects like small and medium scale enterprises and other areas that best address the challenge facing $21^{\text {st }}$ university graduates.

\section{REFERENCES}

Anjum, R. (2015). Design of mobile phone services to support farmers in developing countries. Computer Science, 1-72. (In English)

SKHID No. 2 (160) March-April 2019 
Boaz, S. \& Sanga, C. \& Mussa, M. \& Tumbo, S. \& Mlozi, M \& Haung, R. (2016). Farmers' access and use of mobile phones for improving the coverage of agricultural extension service: A case of Kilosa district, Tanzania. International Journal of ICT research in Africa and the Mid East, 5(1), 35-57. DOI: 10.4018/IJICTRAME.2016010103 (In English)

Chen, Y. F. and Katz J. E. (2009). Extending family to school life: College students' use of the mobile phone. International Journal of Human-Computer Studies, 67(2), 179-191. DOI: https://doi.org/ 10.1016/j.ijhcs.2008.09.002 (In English)

Cole-Lewis, H. \& Kershaw, T. (2010). Text messaging as a tool for behavior change in disease prevention and management. Epidemiologic Reviews. 32(1): 56-69. DOI: 10.1093/epirev/mxq004 (In English)

Ekwueme, A. and Gever, V. C. (2017). Warning Won't Do It: Analysis of communication strategies for enhancing food production in Nigeria. International Journal of communication: an interdisciplinary Journal of communication studies. 21: 47-57. (In English)

Ezeah, G. E. and Gever, V. C. (2017). Youths' perceptions of media campaigns on participation in agriculture in Enugu State. International Journal of Communication: an interdisciplinary Journal of communication studies. 21: 46-55. (In English)

Fjeldsoe, B. \& Marshall, A. and Miller, Y. (2009). Behavior change interventions delivered by mobile telephone short-message service. American Journal of Preventive Medicine. 36 (2): 165173. DOI: https://doi.org/10.1016/j.amepre.2008.09.040 (In English)

Franklin, V. L. \& Waller, A. \& Pagliari, C. \& Greene, S. A. (2006). A randomized controlled trial of Sweet Talk, a text messaging system to support young people with diabetes. Diabetic Medicine 23: 1332-1338. DOI: https://doi.org/10.1111/j.1464-5491.2006.01989.x (In English)

Gever, V. C. and Nwabuzor, M. N. (2014). Strategic communication and information control: A case study of the outbreak of the Ebola Virus Disease in Nigeria. Nigerian Journal of the Humanities, 20, 14-23. (In English)

Haapala, I. \& Barengo, N. C. \& Biggs, S. \& Surakka, L. \& Manninen, P. (2009). Weight loss by mobile phone: a 1-year effectiveness study. Public Health Nutrition. 12 (12): 2382-2391. DOI: https://doi.org/10.1017/S1368980009005230 (In English)

International labour Organization (2016). World employment social outlook. Retrieved from: http://www.ilo.org/wcmsp5/groups/ public/dgreports/dcomm/publ/documents/publication/ wcms_513739.pdf (Accessed: 01.10.2018)

$\mathrm{Li}, \mathrm{H}$. Z. (2006). Backchannel responses as misleading feedback in intercultural discourse. Journal of Intercultural Communication Research, 35, 2: 99-116. DOI: https://doi.org/10.1080/ 17475750600909253 (In English)

Li-Shia, H. \& Yu-Jen, C. \& I-Ting, L. (2007). Effects of Perceived Risk, Message Types, and Reading Motives on the Acceptance and Transmission of Electronic Word-of-Mouth Communication. Contemporary Management Research, 3 (4): 299-312. DOI: https:/ /doi.org/10.7903/cmr.93 (In English)

McLuhan, M. \& Fiore, Q. (1967). The medium is the massage: An inventory of effects. New York: Bantam. (In English)

National Archives (2013). Effective communications: Raising the profile of your archive service. Retrieved from: http:// www.nationalarchives.gov.uk/documents/archives/effectivecommunications.pdf (Accessed: 12.01.2019)

Nguyen, D. and Fussell, S. (2013). Effects of message content on cognitive and affective processes in cross-culture and sameculture Instant Messaging Conversations. Into the Petri Dish: Culture and Collaboration, 19-31. (In English)

Nigerian Communications Commission (2017). Industry statistics. Retrieved from: https://www.ncc.gov.ng/stakeholder/ statistics-reports/industry-overview\#view-graphs-tables-2 (Accessed: 28.12.2018).

Ogunyemi, O (2010). Consumption and (in)appropriate use of mobile phone among teenage Africans in the UK. Lincolnshire, England. (In English)

Otondo, R. F. \& Van Scotter, J. R. \& Allen, D. G. and Palvia, P.
(2008). The complexity of richness: Media, Message, and Communication Outcomes. Information \& Management, 40, 2130. DOI: https://doi.org/10.1016/j.im.2007.09.003 (In English)

Paul, C. (2011). Strategic Communication: Origin, Concept and Current Debates. Santa Barbara: Praeger. (In English)

Riffe, D. \& Lacy, S and Fico, F. (2005). Analyzing media messages: Using quantitative content analysis in research. New Jersey: Lawrence Erlbaum Associates. (In English)

United Nations Children's Fund (2005). Strategic Communication: For Behavior and Social Change in South Asia. New York: UNICEF. (In English)

Valk, J. \& Rashid, A. T. and Elder, L. (2010). Using Mobile Phones to Improve Educational Outcomes: An Analysis of Evidence from Asia. The International Review of Research in Open and Distributed Learning, 11, (1): 1-20. DOI: https://doi.org/10.19173/ irrodl.v11i1.794 (In English)

Walsh, S. \& White, K. and Young, R. (2010). Needing to connect: The effect of self and others on young people's involvement with their mobile phones. Australian Journal of Psychology. 62(4): 194-203. DOI: https://doi.org/10.1080/00049530903567229 (In English)

Whittaker, R., Borland, R., Bullen, C., Borland, R. \& Rodgers, A. and $\mathrm{Gu}, \mathrm{Y}$. (2012). Mobile phone-based interventions for smoking cessation. Cochrane Database System Review 7(4). Retrieved from: http://onlinelibrary.wiley.com/doi/10.1002/14651858.CD006611.pub3/abstract DOI: 10.1002/14651858.CD006611.pub3 (In English)

Wigington, P. (2008). Clear messages for effective communication. Journal of Environmental Health, 70 (10): 71-73. (In English)

Wimmer, R. D. and Dominick, J. R. (2013). Mass media research: An introduction. Belmont Wadsworth. (In English)

\section{LIST OF REFERENCE LINKS}

Anjum R. Design of mobile phone services to support farmers in developing countries. Computer Science, 2015. P. 1-72.

Boaz S., Sanga C., Mussa M., Tumbo S., Mlozi M., Haung R. Farmers' access and use of mobile phones for improving the coverage of agricultural extension service: A case of Kilosa district, Tanzania. International Journal of ICT research in Africa and the Mid East. 2016. 5(1), 35-57. DOI: 10.4018/IJICTRAME.2016010103.

Chen Y. F., Katz J. E. Extending family to school life: College students' use of the mobile phone. International Journal of HumanComputer Studies. 2009. 67(2), 179-191. DOI: https://doi.org/ 10.1016/j.ijhcs.2008.09.002.

Cole-Lewis H., Kershaw T. Text messaging as a tool for behavior change in disease prevention and management. Epidemiologic Reviews. 2010. 32(1): 56-69. DOI: 10.1093/epirev/mxq004.

Ekwueme A., Gever V. Warning Won't Do It: Analysis of communication strategies for enhancing food production in Nigeria. International Journal of communication: an interdisciplinary Journal of communication studies. 2017. 21: 47-57.

Ezeah G. E., Gever V. C. Youths' perceptions of media campaigns on participation in agriculture in Enugu State. International Journal of Communication: an interdisciplinary Journal of communication studies. 2017. 21: 46-55.

Fjeldsoe B., Marshall A., Miller Y. Behavior change interventions delivered by mobile telephone short-message service. American Journal of Preventive Medicine. 2009. 36 (2): 165-173. DOI: https:/ /doi.org/10.1016/j.amepre.2008.09.040.

Franklin V. L., Waller A., Pagliari C., Greene S. A. A randomized controlled trial of Sweet Talk, a text messaging system to support young people with diabetes. Diabetic Medicine. 2006. 23: 13321338. DOI: https://doi.org/10.1111/j.1464-5491.2006.01989.x.

Gever V. C., Nwabuzor M. N. Strategic communication and information control: A case study of the outbreak of the Ebola Virus Disease in Nigeria. Nigerian Journal of the Humanities. 2014. 20, 14-23.

Haapala I., Barengo N. C., Biggs S., Surakka L., Manninen P. Weight loss by mobile phone: a 1-year effectiveness study. Public Health Nutrition. 2009. 12 (12): 2382-2391. DOI: https://doi.org/ $10.1017 / \mathrm{S} 1368980009005230$. 
International labour Organization. World employment social outlook. 2016. URL: http://www.ilo.org/wcmsp5/groups/public/ dgreports/dcomm/publ/documents/publication/wcms 513739.pdf (Accessed: 01.10.2018).

Li H.Z. Backchannel responses as misleading feedback in intercultural discourse. Journal of Intercultural Communication Research. 2006. 35, 2: 99-116. DOI: https://doi.org/10.1080/ 17475750600909253

Li-Shia H., Yu-Jen C., I-Ting L. Effects of Perceived Risk, Message Types, and Reading Motives on the Acceptance and Transmission of Electronic Word-of-Mouth Communication. Contemporary Management Research. 2007. 3 (4): 299-312. DOI: https://doi.org/10.7903/cmr.93.

McLuhan M., Fiore Q. The medium is the massage: An inventory of effects. New York: Bantam, 1967

National Archives Effective communications: Raising the profile of your archive service. 2013. URL: http://www.nationalarchives.gov.uk/documents/archives/effective-communications.pdf (Accessed: 12.01.2019).

Nguyen D., Fussell S. Effects of message content on cognitive and affective processes in cross-culture and same-culture Instant Messaging Conversations. Into the Petri Dish: Culture and Collaboration. 2013. 19-31.

Nigerian Communications Commission Industry statistics. 2017. URL: https://www.ncc.gov.ng/stakeholder/statistics-reports/ industry-overview\#view-graphs-tables-2 (Accessed: 28.12.2018).

Ogunyemi O. Consumption and (in)appropriate use of mobile phone among teenage Africans in the UK. Lincolnshire, England 2010 .

Гевер Верлумун Селестин,

Університет Нігерї (м. Нсукка, итат Енугу, Нігерія)

e-mail: Encyclopeadia100@gmail.com,ORCID 0000-0003-0618-5352
Otondo R. F., Van Scotter J. R., Allen D. G., Palvia P. The complexity of richness: Media, Message, and Communication Outcomes. Information \& Management, 2008. 40, 21-30. DOI: https:/ /doi.org/10.1016/j.im.2007.09.003.

Paul C. Strategic Communication: Origin, Concept and Current Debates. Santa Barbara: Praeger, 2011.

Riffe D., Lacy S., Fico F. Analyzing media messages: Using quantitative content analysis in research. New Jersey: Lawrence Erlbaum Associates, 2005.

United Nations Children's Fund. Strategic Communication: For Behavior and Social Change in South Asia. New York: UNICEF, 2005.

Valk J., Rashid A. T., Elder L. Using Mobile Phones to Improve Educational Outcomes: An Analysis of Evidence from Asia. The International Review of Research in Open and Distributed Learning. 2010. 11, (1): 1-20. DOI: https://doi.org/10.19173/irrodl.v11i1.794.

Walsh S., White K., Young R. Needing to connect: The effect of self and others on young people's involvement with their mobile phones. Australian Journal of Psychology. 2010. 62(4): 194-203. DOI: https://doi.org/10.1080/00049530903567229.

Whittaker R., Borland R., Bullen C., Borland R., Rodgers A. and Gu Y. Mobile phone-based interventions for smoking cessation. Cochrane Database System Review. 2012. 7(4). URL: http:// onlinelibrary.wiley.com/doi/10.1002/14651858.CD006611.pub3/ abstract. DOI: $10.1002 / 14651858 . C D 006611$.pub3.

Wigington $\mathrm{P}$. Clear messages for effective communication. Journal of Environmental Health. 2008. 70 (10): 71-73.

Wimmer R. D., Dominick J. R. Mass media research: An introduction. Belmont Wadsworth, 2013.

\section{ВПЛИВ СМС-ПОВІДОМЛЕНЬ НА ПРОЦЕС ПРАЦЕВЛАШТУВАННЯ БЕЗРОБІТНИХ МОЛОДИХ СПЕЦІАЛІСТІВ З УНІВЕРСИТЕТСЬКОЮ ОСВІТОЮ ДО СІЛЬСЬКОГОСПОДАРСЬКИХ ПІДПРИЕМСТВ НІГЕРІЇ (ІСТОРИКО-СОЦІОЛОГІЧНЕДОСЛІДЖЕННЯ)}

У статті проаналізовано вплив 412 смс-повідомлень від Mtn Nigeria agro info Services Added Value, які протягом 2018 р. надсилались випускникам університетів із сільськогосподарськими спеціальностями. Автором був вивчений зміст цих повідомлень та їх ефективність у прийнятті рішень молодими спеціалістами щодо власного працевлаштування до сільськогосподарських підприємств Нігерії. Задля досягнення цього завдання автор здійснив поділ усього масиву смс-повідомлень на чотири категорії ("доказові", "локальні", "дескриптивні" та "ударні"). 3 них "доказові" повідомлення були найефективнішими в комунікації, спонукаючи безробітних до прийняття конструктивних рішень щодо свого працевлаштування. Загалом результати дослідження свідчать про те, що повідомлення, надіслані на мобільні телефони абонентів, є дуже ефективних засобом у залученні кваліфікованих спеціалістів до роботи в аграрному секторі країни. Окрім історичної, важливою $є$ й соціологічна компонента даного дослідження, бо безробіття випускників університетів робить їх вразливими, і до того ж може мати негативний вплив на суспільство. Важливим є й те, що це дослідження може прислужитись й до позитивних змін у деяких поведінкових стереотипах, бо нині мобільний телефон є дуже ефективним засобом не лише у передачі повідомлень, але й у формуванні певних смаків та ціннісних уявлень. Нарешті, отримані результати дослідження впливатимуть на змістовне наповнення контенту для користувачів мобільних телефонів, оскільки вони свідчать про доволі суттєву різноаспектну ефективність згадуваних категорій смс-повідомлень. Відтак найголовнішою інновацією даної статті є доведення впливу мобільного зв'язку на важливі поведінкові рефлекси, а поданий в ній фактаж та сформульовані висновки будуть корисними та повчальними як для постачальників телекомунікаційних послуг та експертів 3 комунікації, так і для менеджерів аграрних підприємств, соціальних працівників та дослідників даної проблематики. Найважливішим результатом даного дослідження є доведення того, що завдяки отриманню безробітними випускниками університетів агроінформаційних підказок значна їх частина зуміла працевлаштуватись, водночас ті, хто не зважив на цю інформацію, залишалися безробітними.

Ключові слова: сільське господарство; спілкування; повідомлення; випускники університетів; участь.

(C) Gever Verlumun Celestine

Надійшла до редакції: 18.02.2019

Прийнята до друку: 03.04.2019 